\title{
Factors Determining the Asymmetrical Division of Value Created by Companies
}

\author{
Bogusław Gulski \\ Faculty of Economics \\ Maria Curie-Sktodorwsk University in Lublin, Poland \\ gulsbog@poczta.umcs.lublin.pl
}

\begin{abstract}
The present paper discusses the issue of value capturing. The author's objective was to identify factors determining the character of value capturing. In order to meet the objective, value capturing, along with several variations of the phenomenon, were identified. Next, an analysis of two companies, in light of value capturing and factors determining the character of the phenomenon was conducted. Results indicate that the character is determined by endogenous factors associated with the process of creating and transforming value by companies.

Purpose - The aim of the paper is to identify factors determining the specific division of value created by companies.

Methods - The study utilized a case study approach which compares a pair of companies. The study compared the attitude of other companies and their approach towards the abovementioned pair, which may be justified by sensitivity of some areas of the issue. The selection of the case study approach results from an early stage of studies on value capturing.

Results - Research results indicate that companies with limited capability for independent transformation of use value into exchange value, insufficient realization of some activities in value chain in relation to needs, and poor tangible and intangible assets, are prone to asymmetrical division of value.

Limitations - In general, qualitative studies precede quantitative ones, and enable more general conclusions to be drawn. Therefore, further studies on a more sizeable sample are feasible in order to reach more applicable conclusions and for them to serve as a basis for actions to be undertaken by companies.

Practical implications - Results of the study allow general guidelines for developing business models and determining direction of development for companies to be established.

Novelty of the study - It seems that the present study is relatively novel due to a short period of interest in value capturing, and consequently, few publications discussing the issue available. Further studies associated with the present issue ought to examine pairs of cooperating entities which divide value asymmetrically. However, it requires methods of collecting sensitive data to be developed.
\end{abstract}

Keywords - company, case study, value creation, value capturing.

\section{Introduction}

Studies in the field of management constantly evolve and their subject matter is so complex as to prevent the development of a unified approach to the matter. Value capturing ought to be considered as belonging to relatively new fields of interest

Psynargia

International Journal of Synergy and Research Vol. 5, 2016 pp. $79-90$ 
IJSR 5 in management, especially the issue of strategic management. The phenomenon of value capturing is associated with exchange value companies have at their disposal as a result of a sale of a product which possesses a use or emotional value in particular. Another type of value which may be captured is innovation value. However, it is of no concern in the present paper. Due to a relative novelty of the subject, the literature proposes various definitions of value capturing. The paper offers means for specifying the term.

The aim of the paper is to identify factors determining the character of value capturing by companies. Due to the novelty of the subject matter, the study applied the case study method which compared a pair of businesses. Value capturing was evaluated in pairs whose constituting elements always encompassed the assessed company. The premise was made that each of the companies was a member of several such pairs. The studied businesses represent similar market branches. Therefore, it is primarily endogenous factors which exert impact upon possible differences in value capturing by the companies. The paper encompasses four sections. The first discusses the phenomenon of creating and capturing value by companies. The second outlines research methods. The third presents research results. The final section offers conclusions.

The paper fits the framework of situational idea of management. It describes phenomena, indicates their effects, but does not identify cause-effect mechanisms which lead up to these.

\section{Creating and capturing value by companies}

Jacobides, MacDuffie and Tae claimed that research which pertained to strategies and was conducted in the first decade of the $21^{\text {st }}$ century, strove to understand correlated systems composed of complementary objects (Jacobides, MacDuffie and Tae, 2012). A growing interest in such systems proved the existence of a need for understanding the way institutions which develop complex products, cooperate in order to create value, and subsequently divide it among themselves. A similar view was expressed by Lavie, who claimed that numerous studies of strategic networks almost exclusively focused on creating value and disregarded value capturing altogether (Lavie, 2007). In addition, Jacobides et al. observed that the hitherto analytical tools possess limited capacity for explaining the division of value among cooperating businesses. They also stated that the issue of value migration, considered in terms of the means and causes of its shift in value chains, was largely neglected (Jacobides, MacDuffie and Tae, 2012). It seems that the above-mentioned phenomena stem from the hitherto course of strategic management's development based upon the strategic question of "What are the sources of sustainable competitive advantage of a company?". As a result of the interest in this field becoming broadened, the question has been recently replaced by the following: "How can a company create and capture value?". The question reflects the recognition of the fact that competitive advantage stems from two key activities: creating and capturing value. According to the above-mentioned authors, few studies focus on this critical question (Nickerson, Silverman and Zenger, 2007). A similar conclusion was made in Polish literature by Koźmiński (2004, p. 120, 121) and Obłój (2002, p. 79), among others. Such observations resulted in the emergence of the premise that if companies aim to create or boost value, then successful companies and their strategies must not 
be limited to a mere achievement of competitive advantage, but ought to constantly search for new value streams. Businesses which successfully create value, shape their success by developing such strategies and structures which ensure successful methods of creating new value. The extent to which processes in companies generate strategic rents is strongly associated with the companies' capability for permanent identification of problems and swift generation of successful solutions. This is due to the fact that it is likely that value will flow towards companies which develop permanent capacity for identification and solution of problems (Nickerson, Silverman and Zenger, 2007).

The process of creating and capturing value by businesses may be outlined by a diagram (see Figure 1), which forms a basis for further discussion.

In the diagram, companies A and B develop relations and contribute a part of their resources in order to create use value $U$, which in the process of a sales transaction,

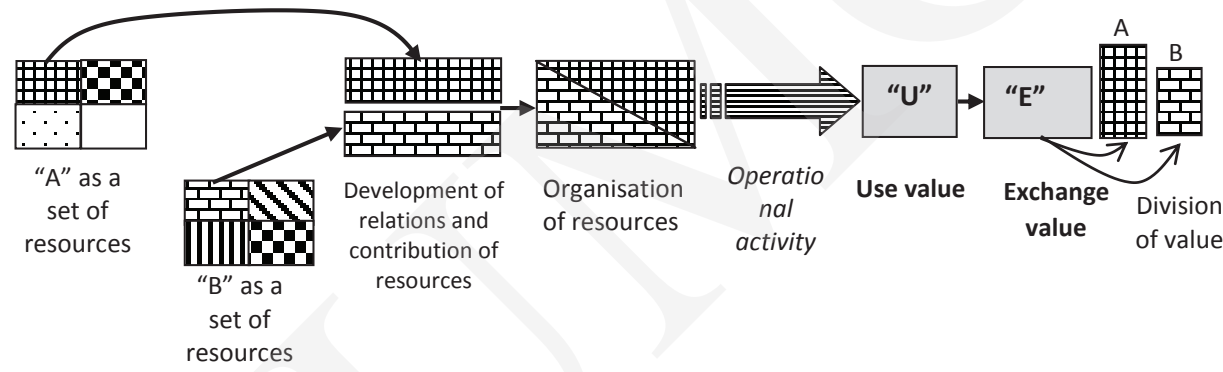

Source: Author's own study.

is transformed into exchange value $\mathrm{E}$ in the form of the mathematical product of the unit price and the number of items sold. Subsequently, value E is divided in a specified proportion between the companies and captured/appropriated by each of them.

The phenomenon of value capturing is defined in the literature of the subject by means of various synonyms such as: value appropriation, value realization, value dispersion, value distribution, and value appropriation (Fisher, 2011, p. 12). To present the idea, the following analogy may be used. If the value created by companies is represented as a pie, then the captured value denotes the part of the pie which is obtained by parties participating in value creation (Gulati, Wang, 2003, p. 209). As a consequence, for the purpose of the present discussion, value capture, which in numerous papers is not defined, has been determined to denote "ensuring economic value remains at the company's disposal".

Slywotzky, Morrison and Andelman approached value capturing pragmatically and observed that, traditionally, it occurs via a sale of products and charging a fee for them. In addition, modern businesses may capture value originating from credits, complementary products, presence in further sections of value chain, and franchising/ licensing (Slywotzky, Morrison and Andelman, 2000, p. 27). Innovative business models of companies augment the number of such means. However, the fact that the authors do not consider value capture in relation to the division of value among parties
Factors Determining the Asymmetrical Division of Value Created by Companies

Figure 1.

An overview of the process of creating and dividing value by a pair of companies 
IJSR 5

\section{Figure 2.}

Spectrum of possible value capturing by an individual company
Figure 3.

Scenarios of value capturing by companies contributing to its creation, but merely to the fact of value capture itself, is noteworthy.

Studies pertaining to cooperation of organizations which co-created value, frequently focused on the creation of relational rent (Dyer and Singh, 1998). However, it was only in the first decade of the $21^{\text {st }}$ century that the discussion of the way the rent reaches individual partners participating in relations was undertaken (Lavie, 2006). Earlier studies, which evaluated asymmetrical distribution of value, and joint and individual benefits obtained from the participation in the relations (Khanna et al., 1998), indicated that such benefits uphold permanent cooperation. However, these studies also devoted less attention to value capturing. Empirical studies which revealed the asymmetry in the return rate for partners participating in relations, were conducted merely on the level of pairs of entities e.g. Gulati and Wang, (2003).

These observations suggest that when considering value capturing, the asymmetrical division and capture of the created value ought to be taken into account. As a consequence of embracing the definition of value capturing and admitting the existence of asymmetry in the division of value, the premise can be made that, from the point of view of value capturing by a particular company, the situation may be described by means of the spectrum outlined in Figure 2.

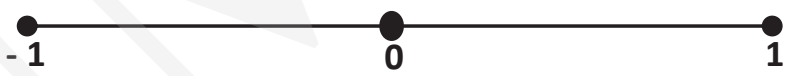

1 - Situation where the whole value created jointly with another entity was captured by the studied company; asymmetrical value capturing;

$\mathbf{0}$ - Situation where the created value was captured by companies proportionately to their contribution to value creation; symmetrical value capturing;

-1 - Situation where the whole value was captured by the business which took part in value creation along with the studied company; asymmetrical value capturing.

Source: Author's own study.

In order to offer a comprehensive view of the process of value capturing, the situation of at least two entities jointly contributing to value creation must be considered. This can be achieved by applying the model presented in Figure 3.

In Figure 3, the rectangular area denotes the total value jointly created by two companies, $\mathrm{A}$ and $\mathrm{B}$. The premise was made that $\mathrm{A}$ and $\mathrm{B}$ proportionately contributed

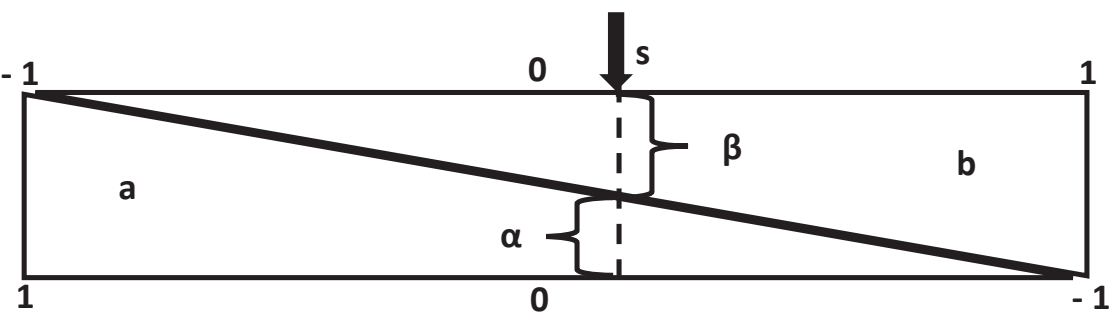

Source: Author's own study. 
to creating the value. Area $a$ denotes value created by A, and area marked $b$ indicates value created by B. Due to the fact that various proportions of captured value's division may emerge, Figure 3 features a pointer $s$ which indicates a particular division of the captured value between the companies. In Figure 3, in the situation indicated by pointer $s$, the share of value captured by A is denoted by section $\alpha$. Analogically, the share of value captured by $\mathrm{B}$ is denoted by section $\beta$. As far as other situations which may occur in the division of value are concerned, they will fit the spectrum outlined in Figure 3. Starting with the left-hand side of the spectrum, it describes extremely asymmetrical value capturing in which A captures the whole value. On the other hand, the right-hand side of the spectrum presents equally extreme asymmetrical division in which it is $\mathrm{B}$ which appropriates the value. Asymmetrical division of value denotes that one of the companies extracts the value belonging to the other entity, whereas the other entity loses the value appropriated by the first. A division of the created value which would follow the proportion marked by point 0 in Figure 3, will be called symmetrical. Such a division constitutes a reference point for determining the share of extracted or lost value. Therefore, it can be said that value capturing may take on the form of extracting the whole value created jointly by entities by a single company, a symmetrical division of value enabling due share to be captured, or the loss of the whole created value, which is appropriated by the cooperating entity.

The transition of pointer $s$ between the extreme ends of the rectangle results from phenomena whose identification constitutes the objective of the present study.

\section{Methods}

The study utilized an inductive approach. It belongs to empirical methods whose purpose is to "search for the truth on the basis of experience, and strive to ensure that reality is adequately reflected in scientific cognition" (Pytkowski, 1985, p. 122). Induction is a means for cognizing reality. Its character is always incomplete (Sułkowski, 2012, p. 296). Induction is characterized by the fact that a research problem is defined on the basis of an existing theory to a limited degree, and instead it is largely based upon researchers' intuition. Generally, such an approach is applied in cases where theoretical bases of the studied issue are insufficient, or when a particular field requires innovative theoretical solutions to be developed (Zaborek, 2007, pp. 270-271). The application of an inductive approach is justified in e.g. cases where researchers are not familiar with activities undertaken by practitioners, which results in the former's inability to offer adequate explanations and course of action based on theories (Benbasat, Goldstein and Mead, 1987).

In order to achieve the study's aims, qualitative research, which in case of some scientific fields usually precedes quantitative studies, was conducted. Moreover, quantitative studies, which frequently make use of correlative methods, do not evaluate mechanisms of phenomena directly (Bromiley and Johnson, 2005). In addition, Miller and Tsang observed that the greatest number of empirical studies in the field of strategic management applied correlative methods, which, however, did not directly test mechanisms explaining theories offered by their authors (Miller, Tsang, 2011). Therefore, interest in determining factors influencing value capturing became decisive
Factors Determining the Asymmetrical Division of Value Created by Companies 
IJSR 5 as far as the selection of qualitative studies is concerned. Due to the fact that the subject matter of the study and paper revolves around the so-called dark side of organizations (see e.g. Vaughan, 1999), the study utilized structured interview (see Yin, 2009) and a standardized questionnaire. Respondents (the President of the Board in $\mathrm{A}_{1}$, and the Chief Financial Officer in $\mathrm{A}_{2}$ ) answered questions connected with relations of their organizations with partners. Questions pertained to value capturing. Such a procedure results from sensitive character of some issues and possible apprehension towards answering such queries in case of companies which may have applied the abovementioned value extraction.

\section{Case study}

The case study examines two companies named $A_{1}$ and $A_{2}$ (non-disclosure was a prerequisite posed by respondents). Both companies were active in the production of metal elements. Both belong to the sector of large enterprises. $\mathrm{A}_{1}$ is larger than $\mathrm{A}_{2}$. $\mathrm{A}_{1}$ may be considered as one applying advanced technologies, whereas $\mathrm{A}_{2}$ utilized traditional technologies well established in the sector. Both companies are specialized and conduct serial production, thus, their relatively small basic product range, and little room for product development. $\mathrm{A}_{1}$ sold relatively large number of products to few recipients, who were generally their end users. They appreciated the quality of $\mathrm{A}_{1}$ 's products. $\mathrm{A}_{2}$ also sold to relatively few recipients (more than $A_{1}$ though). However, in this case, these were intermediaries offering products to end users. Even though $\mathrm{A}_{2}$ 's quality was good, its clients' approach to quality varied, and not all of them required its high level. When confronted with suppliers of inferior-quality goods, $\mathrm{A}_{2}$ was at a disadvantage because it was forced to enter into price competition.

$\mathrm{A}_{1}$ conducted primarily a make-to-order production, and sold only $15-20 \%$ of their production directly on the market. Reasons for selecting $\mathrm{A}_{1}$ 's products included a lower price of goods in general, with the quality requirements set by recipients maintained. $\mathrm{A}_{1}$ was at a disadvantage due to the lack of its own, recognizable trademark. Their products were positioned between goods by leading producers and mass products made in China. The products were of high quality and were manufactured by a producer known internationally but whose reputation has not been recognized. On the other hand, reasons for selecting $\mathrm{A}_{2}$ were more diversified. Large wholesalers recognized the company's qualitative advantage, especially as far as the quality of materials is concerned. Smaller recipients did not recognize this as an asset. For them, price was the critical factor. An Italian recipient was the company's significant partner. The respondent is of the opinion that $\mathrm{A}_{2}$ 's selection by the partner was motivated by its willingness to accept conditions set by the recipient and meet very high quality standards. As a consequence, $\mathrm{A}_{2}$ faced conflicting expectations of key clients, which were difficult to manage simultaneously.

$\mathrm{A}_{1}$ 's main recipients encompassed companies from an automotive sector. They expected annual price reductions. However, such an expectation was formulated with regards to all suppliers in the sector. It was only when the recipient exceeded a particular turnover that they ceased requesting the annual reduction. On the other hand, $\mathrm{A}_{2}$ 's partners' expectations were limited basically to various types of bonuses or discounts, or being granted extended terms of payment. In general, the expectation revolved around 
obtaining the most attractive transaction conditions possible. This was particularly visible in case of group purchasing organizations established by small recipients in order to negotiate the most favorable transaction conditions e.g. in order to change the supplier, the group expected additional discounts from the new supplier, occasionally amounting to $20-30 \%$ of list price. Operations of the other group of recipients, large wholesalers, were assessed as more professional by the respondent. The professional approach was manifested in other parameters of $\mathrm{A}_{2}$ 's product, apart from price, being taken into consideration. With regards to smaller wholesalers, price was the key factor. China-imported products entering Polish market contributed negatively to $\mathrm{A}_{2}$ 's condition. Such products, of inferior quality, were, at the same time, $40 \%$ cheaper than domestic products. $\mathrm{A}_{2}$ 's main competitor, who imported these products to Poland and sold them under an own brand, instigated a price war which affected both producers because it intensified the push for a decrease in prices.

Expectations towards partners differed between both studied companies. $A_{1}$ expected cooperation e.g. in introducing new products or in durability tests. This may be defined as expecting conditions for improving the company's competences, employee development and fuller application of the company's resources. $A_{1}$ 's respondent drew attention to a new kind of expectation, a growing trend in the sector, i.e. recipients ceased to purchase a specific type of product, but listed conditions the product will work in, and expected one meeting these conditions, which justifies development of competences. On the other hand, $\mathrm{A}_{2}$ 's expectations towards their partners were limited to receiving payment for the transaction, which may be justified by the already acquired, satisfactory technological level and high quality of products, but also by financial difficulties, and temporary loss of liquidity, which resulted in the company's focus on solving financial and other short-term problems.

In relations with partners, the two companies were treated differently. Recipients of $\mathrm{A}_{1}$ frequently treated them as an equal partner, a global player. Relations with suppliers depended on the current situation on supply markets. $A_{2}$ considered themselves as having a weaker position than their partners. The company felt under pressure from recipients, who dictated terms both domestically and internationally.

Both companies paid attention to the lasting character of relations with clients. $\mathrm{A}_{1}$ declared that strong emphasis is placed upon maintaining relations with buyers and suppliers, which resulted from the aspiration to utilize the company's growth potential and development. Maintaining relations was also significant for $\mathrm{A}_{2}$, which strived to maintain framework contracts (their terms were negotiated annually). In addition, they provided marketing support to recipients, and went as far as to offer financial aid to this end. Team building events were held annually. However, such an activity was exploited and served to gain further concessions. $A_{2}$ 's respondent observed that relations between entities in the sector were perceived as a zero-sum game. Such perception of relations did not contribute to maintaining lasting relations and cooperation between business entities.

$\mathrm{A}_{1}$ did not perceive imbalance in relations with partners. The claim is justified by the fact that e.g. $A_{1}$ 's employees completed internships in their partners' organizations, which was evaluated very positively because it offered learning opportunities. Moreover, in the course of their internships, recipients' employees engaged in assistance in e.g.
Factors Determining the Asymmetrical Division of Value Created by Companies 
IJSR 5 organizing production in a way enabling cost savings. However, in the opinion of $A_{1}$, this was done in order to obtain a price reduction motivated by the savings. The only manifestation of imbalance was the trend to conceal outcomes of some contractual obligations. In relations with suppliers of materials or services $\mathrm{A}_{1}$ did not perceive imbalance, which justifies the claim that these relations were merely slightly, if at all, dominated by partners. On the other hand, $\mathrm{A}_{2}$ perceived imbalance primarily in relations with recipients, who being aware of a difficult situation of producers, were uncompromising in manifesting their dependence on trading companies. They did that during face-to-face meetings, in the course of negotiations, and in other ways as well. Conversely, $\mathrm{A}_{2}$ 's relations with suppliers were characterized by balance due to the large variety of materials offered on the market. The claim is justified by the fact that generally no contracts were signed but orders simply placed. The above facts prove that $\mathrm{A}_{2}$ was largely dominated in relations with the company's partners.

Respondents from both companies perceived theirpartners'approach as opportunistic. $A_{1}$ indicated two typical instances. First of all, despite the fact that contracts contain formulas determining price increase of sold goods in case external conditions change, especially as far as materials' prices are concerned, recipients happened to disregard such regulations. The occurrence of such a form of opportunism was considered rather rare. The second instance indicated by $\mathrm{A}_{1}$ was a change in the structure of purchased goods by recipients. Such changes revolved around recipients' purchasing smaller quantities of goods which were more profitable, after the contract has been signed. As a consequence, from $A_{1}$ 's perspective, profitability of the contract diminished, and recipients profited. Such forms of opportunism were applied predominantly by recipients utilizing finished goods in their own production processes. On the other hand, end users did not practice such an approach.

According to $\mathrm{A}_{2}$ 's respondent, opportunistic practices were constantly applied to the company. It was mainly wholesalers and group purchasing organizations who practiced these. The practices were manifested in undertaking such behavior as to maximize profits, coerce bonuses or discounts. Production costs incurred by $\mathrm{A}_{2}$ were disregarded in such an approach. In cases where production costs grew, increase in the price of the finished product was not accepted. If, despite the partners' resistance, $\mathrm{A}_{2}$ did increase prices, partners expected the company to alleviate the consequences, by e.g. offering bigger, in terms of absolute value, discounts. Moreover, $\mathrm{A}_{2}$ received direct threats of being abandoned in favor of competition, or bore indirect consequences in the form of decreased turnover in completing annual contracts. In addition, the Italian partner posed extremely high qualitative requirements, ones not practiced in Italy. Should a quality spot check reveal that the number of faulty pieces exceeded the acceptable limit, the whole supplied batch was examined and the cost charged to $\mathrm{A}_{2}$. The company suspected that the Italian partner evaluated their products as low quality on purpose. When assessing the situation of the company, the respondent made a curt observation that partners strove to "coerce anything they possibly could". An exceptional form of opportunism experienced by $\mathrm{A}_{2}$ was the sale of China-made products by the main competitor of the company. These products were manufactured from materials of significantly lower quality than those produced in Poland. To make matters worse, these products bore the competitor's logo and were mixed in with 
their domestic products. According to the company, opportunistic practices against $\mathrm{A}_{2}$ were undertaken primarily by the more profitable recipients who purchased greater quantities of goods, thus those more significant for $\mathrm{A}_{2}$. On the other hand, recipients who initially purchased small quantities, began establishing group purchase organizations, thus consolidating their position against $A_{2}$. Some smaller clients, instead of purchasing goods from the company, turned to buying $\mathrm{A}_{2}$ 's products from large recipients who negotiated better terms. Another form of opportunism, which was not mentioned directly by the respondent, but which surfaced by way of answering a different question, was the sale of goods manufactured by other producers by partners' stores despite exclusivity agreements signed with $\mathrm{A}_{2}$.

$\mathrm{A}_{1}$ did not directly experience value extraction in the three years preceding the study. Such an opinion resulted from the fact that there were no market prices for the company's goods, but contracted prices solely existed. Therefore, any positive differences between the market price and contracted price, considered as an index of extracted value, were impossible to be established. On the other hand, consequences of the above-mentioned opportunistic practices associated with a change in the structure of purchases in the framework of the contract, may be considered a form of value extraction. When concluding a contract with a specified product range, $\mathrm{A}_{1}$ validated prices for particular ranges taking into account costs and profitability of each of them. In general, when changes occurred, the buyer purchased fewer more profitable (typical) products, and more less profitable (rare or non-standard ones). As a consequence, despite the contract being formally completed (the quantity of purchased goods met the order), its profitability lowered. When concluding the contract, $A_{1}$ estimated its profitability. However, the change in the purchase structure may have resulted in a loss or decrease of the profit. Such a loss may be considered as the amount of value extracted by the recipient who applied opportunistic practices. The extraction originating from the lack of recipient's acceptance of $\mathrm{A}_{1}$ 's change (increase) in the price of goods, resulting from the increase of materials' prices, occurred less frequently. Such an extraction emerged in the purchase of goods with a fixed price, but whose manufacture was more expensive than initially calculated. The extent of the extraction was a result of a difference between the actual price of materials and the price featured in calculations. The value, augmented by any surcharge, was de facto appropriated by the recipient. Therefore, in case of $\mathrm{A}_{1}$, two types of extraction can be distinguished: the difference between the profit calculated on the basis of a specific product range structure and the actual profit obtained after the structure was altered, and the difference between the real cost of materials incurred by $\mathrm{A}_{1}$ and the cost of materials featured in the calculation.

In case of $A_{2}$, value extraction in the form of the difference between costs incurred by the company and the amount obtained from buyers was never determined. It was due to the fact that profitability of individual contracts was not calculated. Instead, the calculation encompassed global profitability. It resulted from difficulties in isolating indirect costs from individual orders. Consequently, $\mathrm{A}_{2}$ was able to merely assume that smaller, mass produced goods are less profitable, and larger products more profitable. Therefore, the company may have only suspected that extraction of value may take place in the framework of the contract. On the other hand, having granted the coerced
Factors Determining the Asymmetrical Division of Value Created by Companies 
IJSR 5 discounts, i.e. having experienced the second form of value extraction, $\mathrm{A}_{2}$ was able to calculate the loss and consider it as value extracted by recipients. The existence of value extraction was proven in $\mathrm{A}_{2}$ 's financial results obtained at the end of each month. Therefore, $\mathrm{A}_{2}$ experienced only one, but severe, form of value extractioncoerced discounts. Moreover, it may be suspected that some batches of the company's products were sold below costs, which found confirmation in financial statements of the company.

One of the factors determining $A_{2}$ 's disadvantageous position was the popular familiarity with their problems. Domestic buyers were aware of them and exploited the situation by negotiating with $\mathrm{A}_{2}$ from the position of power. In addition, the Italian partner was also aware of the problems. They failed to find partners for cooperation on their terms, thus exploited $A_{2}$ 's situation. However, the respondent admitted that, objectively, the completion of this particular contract was beneficial for the company.

The study revealed that $\mathrm{A}_{1}$ generally participated in a symmetrical division of value and rarely experienced value extraction. On the other hand, $\mathrm{A}_{2}$ generally participated in an asymmetrical division, which resulted in value extraction conducted by their partners i.e. a loss of value was experienced by $\mathrm{A}_{2}$. Therefore, it seems that, as a consequence, the comparison of the two companies may enable selected factors determining the character of value capturing, especially its symmetry, to be established. The fundamental characteristics of the assessed companies are presented in Table 1.

It seems that key differences between the assessed companies emerge with regards to criteria labeled 6, 7, 8 in Table 1 . However, a question arises whether the differences are of autonomous character or are they a consequence of another phenomenon, maybe of a more general character.

Referring to Figure 1, it may be observed that companies $A_{1}$ and $A_{2}$ differed primarily regarding the ability to transform the created use value into exchange value. Company $\mathrm{A}_{1}$ was in a much better situation in this respect than $\mathrm{A}_{2}$. Moreover, when making a reference to $\mathrm{RBV}$, it may be stated that $\mathrm{A}_{1}$ 's relations with other entities were much more developed, which enabled them to undertake sales activities within the value chain more effectively. To sum up, it may be stated that a company's dependency upon its cooperators, derives from:

- limited ability for independent transformation of use value into exchange value,

- insufficient realization of some activities in the value chain in relation to needs,

- poor tangible and intangible assets,

- contributors to the occurrence of the asymmetrical division of the created value, especially to its loss due to extraction conducted by other entities.

\section{Conclusions}

Value capturing has become one of the vital issues in strategic management. It is considered more important than competitive advantage. Value capturing contributes to companies' success. The conclusion that, for some businesses, the asymmetrical value capturing (referred to as value extraction in the paper) has become a new source of value, can be made. Therefore, establishing factors which determine characteristics of value capturing by businesses has gained significance. 


\begin{tabular}{|c|c|c|c|}
\hline \multirow[t]{2}{*}{ No. } & \multirow[t]{2}{*}{ Criterion } & \multicolumn{2}{|c|}{ Company: } \\
\hline & & $\begin{array}{l}\text { participating in a symmetrical division } \\
\text { of value (not experiencing value } \\
\text { extraction) }\end{array}$ & $\begin{array}{l}\text { participating in an asymmetrical } \\
\text { division of value (experiencing } \\
\text { value extraction) }\end{array}$ \\
\hline 1 & Size & Large & Large \\
\hline 2 & $\begin{array}{l}\text { Opportunity for product } \\
\text { development }\end{array}$ & Limited & Limited \\
\hline 3 & $\begin{array}{l}\text { Assessment of product quality by } \\
\text { recipients }\end{array}$ & High quality of products appreciated & $\begin{array}{l}\text { High, quality of products } \\
\text { appreciated only by some recipients }\end{array}$ \\
\hline 4 & Partners' expectations & Annual price reductions & $\begin{array}{l}\text { Bonuses, discounts, extended terms } \\
\text { of payment }\end{array}$ \\
\hline 5 & Expectations towards partners & $\begin{array}{l}\text { Assistance in consolidation of } \\
\text { company's competences, lasting } \\
\text { relations }\end{array}$ & $\begin{array}{l}\text { Reception of payment for the } \\
\text { transaction, lasting relations }\end{array}$ \\
\hline 6 & Character of relations with partners & Equal partner & Subordination, dependence \\
\hline 7 & $\begin{array}{l}\text { Existence of imbalance in relations } \\
\text { with partners }\end{array}$ & Few cases of imbalance & $\begin{array}{l}\text { Imbalance in relations with some } \\
\text { partners (recipients) }\end{array}$ \\
\hline 8 & Opportunistic practices & $\begin{array}{l}\text { Partners' withdrawal from } \\
\text { arrangements regarding prices, } \\
\text { Change in the structure of purchased } \\
\text { goods }\end{array}$ & $\begin{array}{l}\text { Expectations disregarding } \\
\text { economic realities, } \\
\text { Threats regarding a change of } \\
\text { supplier, } \\
\text { Demanding a discount is associated } \\
\text { with the increase of price }\end{array}$ \\
\hline
\end{tabular}

Table 1.

Influence of fundamental determinants of the companies' operations upon the division of value

Source: Author's own study.

The paper presents results of an analysis evaluating two cases of businesses participating in value creation and capturing. It was observed that features of value capturing, especially "symmetrical" value division and capturing, depend on endogenous factors, the ability to transfer use value into exchange value in particular. In addition, the paper offers directions for prospective studies of value capturing.

\section{References}

Benbasat, I., Goldstein, D. and Mead, M. (1987). The Case Research Strategy in Studies of Information Systems, MIS Quarterly, Vol. 11, No. 3, pp. 369-386.

Bromiley, P., Johnson, S. (2005). Mechanisms and Empirical Research, [in:] D. Bergh and D. Ketchen (Eds.), Research Methodology in Strategy and Management, Vol. 2, JAI Press/ Elsevier, pp. 15-29.

Dyer, J. H. and Singh, H. (1998). The Relational View: Cooperative Strategy and Sources of Interorganizational Competitive Advantage, The Academy of Management Review, Vol. 23, No. 4, (October), pp. 660-679. 
IJSR 5
Fischer, T. (2011). Managing Value Capture. Empirical Analyses of Managerial Challenges in Capturing Value (Dissertation), Technical University of Munich.

Gulati, R. and Wang, L. O. (2003). Size of the Pie and Share of the Pie: Implications of Network Embeddedness and Business Relatedness for Value Creation and Value Appropriation in Joint Ventures, [in:] V. Buskens, W. Raub and C. Snijders (Eds.), The Governance of Relations in Markets and Organizations (Research in the Sociology of Organizations), Vol. 20, Emerald Group Publishing Limited, pp. 209-242.

Jacobides, M. G., MacDuffie, J. P. and Tae, C. J. (2012). When Value Sticks Around: Why Automobile OEMs Still Rule Their Sector, Industry Studies Association Conference, Pittsburgh, PA, May 29-31.

Khanna, T., Gulati, R. and Nohria, N. (1998). The Dynamics of Learning Alliances: Competition, Cooperation, and Relative Scope, Strategic Management Journal, Vol. 19, No. 3, pp. 193-210.

Koźmiński,A. K. (2004). Zarządzanie w warunkachniepewności. Podręcznik dla zaawansowanych (Management under Uncertainty. Advanced Guide), PWN, Warsaw.

Lavie, D. (2006). The Competitive Advantage of Interconnected Firms: An Extension of the ResourceBased View, The Academy of Management Review, Vol. 31, No. 3, (July), pp. 638-658.

Lavie, D. (2007). Alliance Portfolios and Firm Performance: A Study of Value Creation in the U.S. Software Industry, Strategic Management Journal, Vol. 28, No. 12, pp. 1187-1212.

Miller, K. D. and Tsang, E. W. K. (2011). Testing Management Theories: Critical Realist Philosophy and Research Methods, Strategic Management Journal, Vol. 32, No. 2, (February), pp. 139-158.

Nickerson, J. A., Silverman, B. and Zenger, T. (2007). The "Problem" of Creating and Capturing Value, Strategic Organization, Vol. 5, No. 3, pp. 211-225.

Obłój, K. (2002). Tworzywo skutecznych strategii. Na styku starych i nowych reguł konkurencji (Material Effective Strategies. At the Junction of Old and New Competition Rules), PWE, Warsaw.

Pytkowski, W. (1985). Organizacja badań i ocena prac naukowych (Organization of Research and Evaluation of Scientific Papers), PWN, Warsaw.

Slywotzky, A. J., Morrison, D. J. and Andelman, B. (2000). Strefa zysku: strategiczne modele działalności (The Profit Zone: Strategic Business Models), PWE, Warsaw.

Sułkowski, Ł. (2012). Epistemology and Methodology of Management, PWE, Warsaw.

Vaughan, D. (1999). The Dark Side of Organizations: Mistake, Misconduct, and Disaster, Annual Review of Sociology, Vol. 25, No. 1, pp. 271-305.

Yin, R. K. (2009). Case Study Research: Design and Methods (Applied Social Research Methods), Sage Publications, Thousand Oaks.

Zaborek, P. (2007). Studium przypadku jako metoda badawcza (Case Study as a Research Method), [in:] K. Kuciński (Ed.), Doktoranci o metodologii nauk ekonomicznych (Doctoral Students about the Methodology of Economics), SGH, Warsaw. 